\title{
Transition Metal Complexes of Diazenes, XVIII [1] \\ Reactions of 1,2-Diazetines and 1,2-Diazetine-N-oxides with Chromium and Tungsten Carbonyls
}

\author{
A. Albini \\ Istituto di Chimica Organica, Università di Pavia, I-27100 Pavia \\ H. Kisch \\ Max-Planck-Institut für Strahlenchemie, D-4330 Mülheim a. d. Ruhr \\ Z. Naturforsch. 37 b, 468-472 (1982); received November 13, 1981 \\ 1,2-Diazetines, 1,2-Diazetine-N-oxide, Chromium Complexes, Tungsten Complexes \\ Chromium and tungsten carbonyls react with 3,3,4,4-tetramethyl-1,2-diazetine (1) or \\ its mono-N-oxide (2) to form complexes $(\mathbf{1}) \mathbf{M}(\mathrm{CO})_{5},(\mathbf{1})_{2} \mathbf{M}(\mathrm{CO})_{4},(\mathbf{1}) \mathbf{M}_{2}(\mathrm{CO})_{10},(\mathbf{1})_{2} \mathrm{M}_{2}(\mathrm{CO})_{8}$, \\ $(1)_{3} \mathrm{M}_{2}(\mathrm{CO})_{6}$ or $(2) \mathrm{M}(\mathrm{CO})_{5}$ and $(2)_{2} \mathrm{M}(\mathrm{CO})_{4}$, resp. In the reactions of 2 some deoxygenation \\ affords complexes of 1 as by-products. The stability of these and other complexes of the \\ $\mathbf{N}=\mathbf{N}$ group is related to the ring size of the cyclic diazene ligand.
}

\section{Introduction}

The ring size of a cyclic diazene largely determines the type of complex formed by reaction of the $c i s-\mathrm{N}=\mathrm{N}$ bond with a zero-valent transition metal compound [1-7]. The cyclic ligand structure is usually retained in the reactions of five- to sevenmembered diazenes while ring opening and rearrangement via $\mathrm{C}-\mathrm{N}$ and $\mathrm{N}=\mathrm{N}$ bond cleavage occurs with the three-membered diazirines $[3,4]$. In addition, the stability of certain complexes containing the intact diazene ligand seems to be a function of the ring size. These findings may be rationalized by the different properties of the highest occupied molecular orbitals of threemembered rings as compared to five- to sevenmembered ones $[3,6]$. Recently we found that the stability and type of complexes obtained from the four-membered 1,2-diazet-1-ines and iron carbonyls is in accordance with this rationalisation [1]. In this paper we report on the reactions of $3,3,4,4$ tetramethyl-1,2-diazetine (1) and 3,3,4,4-tetramethyl-1,2-diazetine-N-oxide (2) with chromium and tungsten carbonyls.

\section{Results}

Analogously to other diazenes $[8,9]$, the mononuclear complex $\mathbf{3 a}$ is synthesized by reacting $\mathbf{l}$ and $(\mathrm{THF}) \mathrm{Cr}(\mathrm{CO})_{5}$ in tetrahydrofuran (THF) at room temperature. No binuclear complex could be detected by t.l.c. analysis, even when using an excess of the metal carbonyl. Reaction conditions and

$0340-5087 / 82 / 0400-0468 / \$ 01.00 / 0$ yields are summarized in Table I. The structure of 3a follows from a comparison of the physical and chemical properties with those of the analogous $\sigma$-complexes of six-membered diazenes [8-10].

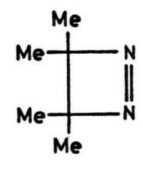

1

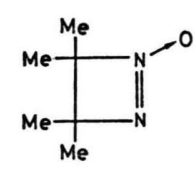

2

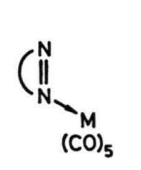

3

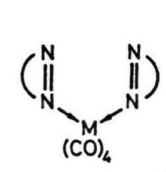

4

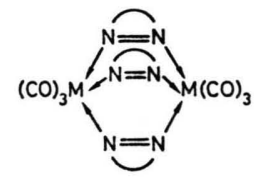

5

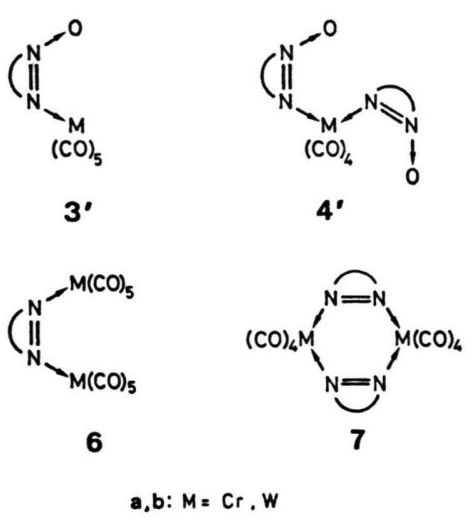

Complex 3a may be crystallized (from petroleum ether) or sublimed to yield intensively yellow coloured leaflets. Upon standing in solution the 
colour changes more to the red and t.l.c. analysis shows the presence of a red complex. Complete conversion of $3 \mathrm{a}$ into the same complex and a new yellow one (4a) is observed on boiling in concentrated benzene solution. The latter complex is identical with the main product formed by the reaction of (norbornadiene) $\mathrm{Cr}(\mathrm{CO})_{4}$ with 1 . From this method of preparation and the close correspondence of the spectroscopic data with those of the previously described cis(2,3-diazanorbornene)2$\mathrm{Cr}(\mathrm{CO})_{4}[8,9]$, we identify the yellow complex as cis-(diazetine $)_{2} \operatorname{Cr}(\mathrm{CO})_{4}$ (4a). The other complex (5a), obtained as dark green crystals soluble with intense red-violet colour, is similarly identified as the triple bridged (diazetine) ${ }_{3} \mathrm{Cr}_{2}(\mathrm{CO})_{6}$ (5a). The analogous 2,3-diazanorbornene complex is also known [8]. Heating of $4 \mathbf{a}$ again affords 5 a, the most stable compound of this series.

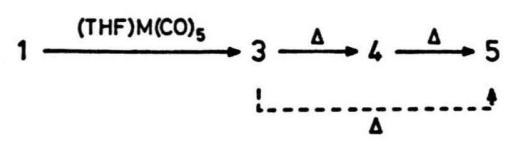

A wider scope of reactivity is found in the reactions of 1 with tungsten carbonyls. In addition to the mononuclear compound $\mathbf{3 b}$, there is formed the single bridged complex $6 \mathrm{~b}$ in the experiments with $(\mathrm{THF}) \mathrm{W}(\mathrm{CO})_{5}$ (see Table I). The proposed structure follows from a comparison of spectral data (Table II) with those of the corresponding diazirine complexes [6,7].

In the reactions with (norbornadiene) $\mathrm{W}(\mathrm{CO})_{4}$ the double bridged metallocycle $\mathbf{7 b}$ is formed in addition to $4 \mathrm{~b}$. Complex $7 \mathrm{~b}$ forms black crystals yielding a dark-green solution. The proposed structure is based on a comparison with analogous complexes of three- and six-membered diazenes [5, 6, 8, 9].

All the tungsten compounds are stable in the solid state at room temperature. However, upon melting they are converted into the triple bridged complex $\mathbf{5 b}$.

The experiments with the diazetine- $\mathrm{N}$-oxide 2 lead predominantly to complexes of type $3^{\prime}$ and $4^{\prime}$. In the reaction with $(\mathrm{THF}) \mathrm{Cr}(\mathrm{CO})_{5}$ some deoxygenation affords minor amounts of $3 \mathrm{a}$. At higher reaction temperatures the deoxygenation becomes more important and the most stable type of diazetine complexes, 5, is obtained; the yields are higher for $\mathrm{M}=\mathrm{Cr}$ than in the case of $\mathrm{W}$ even when using the more reactive $(\mathrm{MeCN})_{3} \mathrm{~W}(\mathrm{CO})_{3}$.

\section{Discussion}

The complexes obtained confirm the assumption [3] that 1,2-diazetines constitute interesting border line cases between small- and large-membered cyclic diazenes. Thus, complexes of type $3,4,5$ can be isolated with four- or higher-membered diazenes but not with three-membered ones, whereas complexes 6 are obtained only in case of three- and fourmembered but not with higher-membered ligands [5-9]. However, metallocycles of type 7 are afforded independent of the ring size. These findings may be rationalized in terms of the variation of electronic and steric properties of the "lone-pair" orbitals $\left(n_{1}, n_{2}\right)$ as a function of ligand ring-size $[1,3]$. With increasing ring size an increasing localisation of the highest occupied molecular orbital, $n_{1}$, on the $\mathrm{N}=\mathrm{N}$ group is expected [1]. Accordingly, the stability of

Table I. Reaction conditions and yields.

\begin{tabular}{|c|c|c|c|c|c|}
\hline Complex & Ligand & $\begin{array}{l}\text { Ratio } \\
\text { (metal/ligand) }\end{array}$ & Solvent & $\begin{array}{l}\text { Reaction } \\
\text { time }[\mathrm{h}]\end{array}$ & $\begin{array}{l}\text { Products } \\
{[\% \text { yield }]^{\mathrm{a}}}\end{array}$ \\
\hline $\begin{array}{l}\mathrm{Cr}(\mathrm{CO})_{5}(\mathrm{THF}) \\
\mathrm{Cr}(\mathrm{CO})_{5}(\mathrm{THF}) \\
\mathrm{Cr}(\mathrm{CO})_{4} \text { (norbornadiene) } \\
\left.\mathrm{Cr}(\mathrm{CO})_{4} \text { (norbornadien }\right)^{2} \\
\mathrm{Cr}(\mathrm{CO})_{6} \\
\mathrm{~W}(\mathrm{CO})_{5}(\mathrm{THF}) \\
\mathrm{W}(\mathrm{CO})_{5}(\mathrm{THF}) \\
\mathrm{W}(\mathrm{CO})_{4} \text { (norbornadiene) } \\
\mathrm{W}(\mathrm{CO})_{4}(\text { norbornadien } \theta) \\
\mathrm{W}(\mathrm{CO})_{3}(\mathrm{MeCN})_{3}\end{array}$ & $\begin{array}{l}\mathbf{1} \\
\mathbf{2} \\
\mathbf{1} \\
\mathbf{2} \\
\mathbf{2} \\
\mathbf{1} \\
\mathbf{2} \\
\mathbf{1} \\
\mathbf{2} \\
\mathbf{2}\end{array}$ & $\begin{array}{l}1 \text { or } 2 \\
1 \\
1 \\
1 \\
1.5 \\
2 \\
1 \\
1 \\
1 \\
1.5\end{array}$ & $\begin{array}{l}\text { THF, r.t. } \\
\text { THF, r.t. } \\
n \text {-hexane, r.t. } \\
n \text {-hexane, r.t. } \\
n \text {-heptane, refluxing } \\
\text { THF, r.t. } \\
\text { THF, r.t. } \\
\text { benzene, r.t. } \\
\text { benzene, r.t. } \\
\text { n-hexane, refluxing }\end{array}$ & $\begin{array}{l}0.75 \\
1 \\
15 \\
15 \\
22 \\
4 \\
4 \\
15 \\
15 \\
15\end{array}$ & $\begin{array}{l}\text { 3a } \mathbf{a}(21), 5 \mathbf{a}(13)^{\mathbf{b}} \\
\mathbf{3}^{\prime} \mathbf{a}(84), \mathbf{3} \mathbf{a}(7) \\
4 \mathbf{a}(30), \mathbf{5} \mathbf{a}(16) \\
4^{\prime} \mathbf{a}(45) \\
5 \mathbf{a}(25) \\
\mathbf{3}_{\mathbf{b}} \mathbf{b}(51), 6 \mathbf{b}(30) \\
3^{\prime} \mathbf{b}(95) \\
4 \mathbf{b}(32), 7 \mathbf{b}(20) \\
4^{\prime} \mathbf{b}(58) \\
\mathbf{3}^{\prime} \mathbf{b}(6), 4^{\prime} \mathbf{b}(14) \\
5 \mathbf{b}(3), 7 \mathbf{b}(2)\end{array}$ \\
\hline
\end{tabular}

a Of isolated products; $\mathrm{b}$ is probably formed during chromatographic separation. 
Table II. Spectral data for complexes 3-7.

\begin{tabular}{|c|c|c|c|c|}
\hline Compound & $\mathrm{IR}^{\mathrm{a}}$ & $\begin{array}{l}\text { UV-VIS } \\
{\left[\varepsilon, \mathrm{Lmol}^{-1} \mathrm{~cm}^{-1}\right]}\end{array}$ & $\begin{array}{l}{ }^{1} \mathrm{H}-\mathrm{NMR}^{\mathrm{b}} \\
{[\delta]}\end{array}$ & $\mathbf{M S}^{\mathbf{c}}$ \\
\hline $3 \mathbf{a}$ & $2069 \mathrm{~m}, 1992 \mathrm{w}, 1942 \mathrm{vs}, 1920 \mathrm{~s}$ & $40.3(4.27), 25.4(3.66)$ & $\begin{array}{l}0.8 \mathrm{~s} \\
0.85 \mathrm{~s}\end{array}$ & 304 \\
\hline $\mathbf{3 b}$ & $2072 \mathrm{~m}, 1982 \mathrm{w}, 1937 \mathrm{vs}, 1918 \mathrm{sh}$ & $40.8(4.92), 34.5(3.54), 25.8(4.03)$ & $\begin{array}{l}0.65 \mathrm{~s} \\
0.7 \mathrm{~s}\end{array}$ & 436 \\
\hline $\mathbf{3}^{\prime} \mathbf{a}$ & $2069 \mathrm{~m}, 1991 \mathrm{vs}, 1915 \mathrm{~s}$ & $40.3(4.49), 25.9(3.92)$ & $\begin{array}{l}0.7 \mathrm{~s} \\
0.9 \mathrm{~s}\end{array}$ & 320 \\
\hline $\mathbf{3}^{\prime} \mathbf{b}$ & $2066 \mathrm{~s}, 1978 \mathrm{~m}, 1930 \mathrm{vs}, 1910 \mathrm{sh}$ & $40.3(5.10), 34.5(3.48), 25.9(3.97)$ & $\begin{array}{l}0.8 \mathrm{~s} \\
1.0 \mathrm{~s}\end{array}$ & 452 \\
\hline $4 \mathbf{a}$ & $2010 \mathrm{~s}, 1909 \mathrm{vs}, 1892 \mathrm{vs}, 1859 \mathrm{vs}$ & $41.1(4.26), 22.8(3.97)$ & $\begin{array}{l}0.8 \mathrm{~s} \\
1.1 \mathrm{~s}\end{array}$ & 388 \\
\hline $4 \mathrm{~b}$ & $2011 \mathrm{~s}, 1899 \mathrm{sh}, 1888 \mathrm{vs}, 1860 \mathrm{~s}$ & $40.5(4.50), 26.2(4.07), 23.7(4.09)$ & $\begin{array}{l}0.8 \mathrm{~s} \\
1.1 \mathrm{~s}\end{array}$ & 520 \\
\hline $4^{\prime} \mathbf{a}$ & $2010 \mathrm{~s}, 1900 \mathrm{vs}, \mathrm{br}, 1852 \mathrm{vs}$ & $40.8(4.18), 24.0(3.83)$ & $\begin{array}{l}0.85 \mathrm{~s} \\
1.3 \mathrm{~s}\end{array}$ & 420 \\
\hline $\mathbf{4}^{\prime} \mathrm{b}$ & $2007 \mathrm{~s}, 1890 \mathrm{vs}, \mathrm{br}, 1850 \mathrm{~s}$ & $\begin{array}{l}40.2(4.34), 36.0(3.89), 27.5(3.80) \\
24.6(3.90)\end{array}$ & $\begin{array}{l}0.8 \mathrm{~s} \\
1.2 \mathrm{~s}\end{array}$ & 552 \\
\hline $\begin{array}{l}5 \mathbf{a} \\
5 \mathbf{b} \\
6 \mathbf{b} \\
7 \mathbf{b}\end{array}$ & $\begin{array}{l}1895 \mathrm{vs}, 1850 \mathrm{~m} \\
1893 \mathrm{vs}, 1846 \mathrm{~s} \\
2055 \mathrm{~s}, 1990 \mathrm{~s}, 1960 \mathrm{sh}, 1935 \mathrm{vs}, 1916 \mathrm{~s} \\
2032 \mathrm{w}, 1991 \mathrm{~s}, 1938 \mathrm{~s}, 1910 \mathrm{vs}, 1873 \mathrm{~s}\end{array}$ & $\begin{array}{l}29.9(3.42), 20.9(3.61), 18.1(4.01) \\
40.8(4.48), 26.8(3.59), 18.6(4.59) \\
30.6(3.44), 25.6(3.94), 18.5(4.03) \\
34.5(4.11), 27.5(4.11), 25.2(4.06), \\
21.1(4.59)\end{array}$ & $\begin{array}{l}0.6 \mathrm{~s} \\
0.9 \mathrm{~s}\end{array}$ & $\begin{array}{l}608 \\
872 \\
760 \\
816\end{array}$ \\
\hline
\end{tabular}

${ }^{\text {a }}$ In $n$-hexane, $\lg \varepsilon ;{ }^{\mathrm{b}}$ in benzene- $\mathrm{d}_{6} ;{ }^{\mathrm{c}}$ ion of highest $m / e$ ratio.

the M-NN bonds should increase in the same direction. This parallels the increasing stability of mononuclear $\sigma$-diazene complexes of iron $[1,3]$ and group VIb carbonyls [5-10] as well as of bis(diazene) $\mathbf{M}(\mathrm{CO})_{4}$ complexes $[8,9]$ with increasing ligand ring size. The stability of single and triple bridged complexes (type 5 and 6 ) may be related to the variation of the angle $\mathrm{M}-\mathrm{N}-\mathrm{N}$ with the ligand ring size [3]. This angle is large enough to avoid a strong steric hindrance between the two $\mathrm{M}(\mathrm{CO})_{5}$ groups in the case of three- and four-membered ligands resulting in stable complexes of type 6 . The observation that only tungsten but no chromium complexes of this type can be obtained with the 1,2-diazetine [1], may be rationalized by assuming that only the W-N bond is long enough to sufficiently separate the two metal carbonyl groups. Contrary to that, a large angle $\mathrm{M}-\mathrm{N}-\mathrm{N}$ gives rise to a destabilisation of complexes of type 5 which cannot be isolated with diazirines as ligands. The fact that metallocycles of type 7 are obtained with all types of ligands may be explained by an additional stabilisation due to a chelate effect and electron delocalisation within the planar six-membered bisdiazene dimetal ring.

The $v(\mathrm{CO})$ absorptions of the diazetine complexes 3 appear in the same range as for the complexes with five- or six-membered diazenes and are shifted by $10-20 \mathrm{~cm}^{-1}$ to lower wavenumbers as compared with the three-membered ligands. This indicates a stronger $\pi$-backbonding to, or poorer $\sigma$-donation from the diazirine ligands. A similar difference is observed for complexes of type 6 .

As already noted in the case of diazetine-N-oxide iron complexes [1], 2 forms mononuclear $\sigma$-complexes completely analogous to 1 . Accordingly, the spectroscopic data of $3^{\prime}$ and $4^{\prime}$ closely correspond to those of 3 and 4 (Tab. II, Fig. 1).

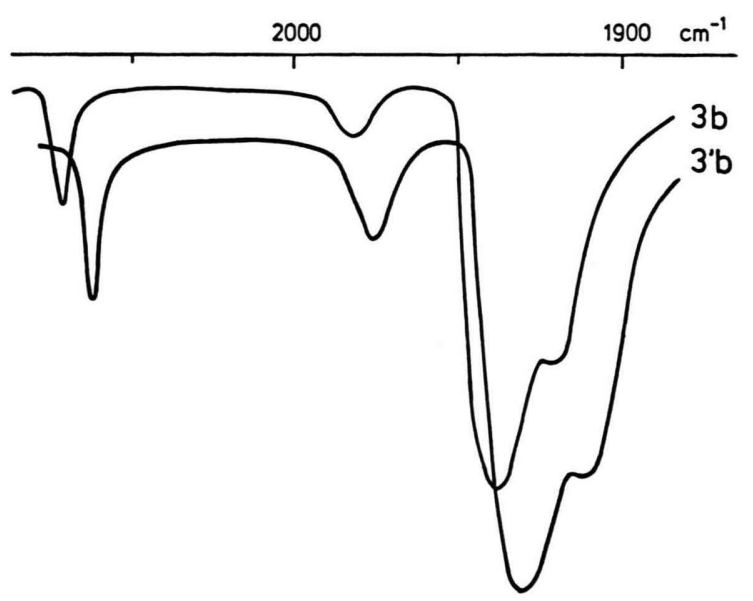

Fig. 1. IR-Spectra of $\mathbf{3} \mathbf{b}$ and $\mathbf{3}^{\prime} \mathbf{b}$ in the range of $1800-2100 \mathrm{~cm}^{-1} ; n$-Hexane, room temperature. 
The mass spectra of $3^{\prime}$ and $4^{\prime}$ exhibit two competing fragmentation pathways: loss of an oxygen atom followed by stepwise loss of CO groups vs. direct loss of the latter, leaving the intact ligand. Although some deoxygenation occurs, particularly with chromium carbonyls, these reaction conditions are not favourable for deoxygenation of these aliphatic azoxy compounds. Better results were recently reported for the deoxygenation of azoxybenzene with $\mathrm{Fe}_{3}(\mathrm{CO})_{12}$ or $\mathrm{Mo}(\mathrm{CO})_{6}$ on alumina [11].

\section{Experimental}

All manipulations with metal carbonyls were carried out under an argon atmosphere. THF was freshly distilled from $\mathrm{LiAlH}_{4}$, hydrocarbon solvents from sodium. 1,2-Diazetine $\mathbf{l}$ and its $\mathrm{N}$-oxide [12], (norbornadiene) $\mathrm{M}(\mathrm{CO})_{4}(\mathrm{M}=\mathrm{Cr}$ [14], $\mathrm{W}$ [15]), and $(\mathrm{MeCN})_{3} \mathrm{~W}(\mathrm{CO})_{3}$ [16] were prepared and purified according to the literature. Silica gel was degassed and kept under argon. Melting points were measured in closed capillary tubes and are uncorrected. Spectra were recorded on the following instruments: Perkin-Elmer 200, 257, R 12 (UV, IR, NMR) and Du Pont 492-B (MS).

\section{Reactions with ( $\mathrm{THF}) \mathrm{Cr}(\mathrm{CO})_{5}$}

$0.66 \mathrm{~g}(3 \mathrm{mmol})$ of $\mathrm{Cr}(\mathrm{CO})_{6}$ are irradiated in $90 \mathrm{ml}$ THF with a Pyrex-filtered medium pressure mercury arc in an immersion well apparatus, after purging with argon. The irradiation is stopped when one equivalent of $\mathrm{CO}$ is evolved, $0.17 \mathrm{~g}$ or $0.34 \mathrm{~g}$ of 1 ( 1.5 or $3 \mathrm{mmol}$ ) or $0.36 \mathrm{~g}(3 \mathrm{mmol}$ ) of 2 is added and the solution is stirred at r.t. until the reaction is judged to be completed (t.l.c. analysis). The solvent is evaporated and products are separated by chromatography on silica gel. Complexes 3 are crystallized from petroleum ether, the others from toluene/petroleum ether mixtures.

Reactions with $(\mathrm{THF}) \mathrm{W}(\mathrm{CO})_{5}$

As described above using $1.05 \mathrm{~g}(3 \mathrm{mmol})$ of $\mathrm{W}(\mathrm{CO})_{6}$.

\section{Reactions with (norbornadiene) $M(C O)_{4}$,} $M=C r, W$

$3 \mathrm{mmol}$ of (norbornadiene) $\mathrm{M}(\mathrm{CO})_{4}$ and $0.17 \mathrm{~g}$ $(1.5 \mathrm{mmol})$ of 1 or $0.18 \mathrm{~g}(1.5 \mathrm{mmol})$ of 2 are stirred in $40 \mathrm{ml}$ of $n$-hexane at r.t. When the reaction is finished, as determined by t.l.c. analysis, the solution was worked up as above.

\section{Reaction with $\mathrm{Cr}(\mathrm{CO})_{6}$}

$0.33 \mathrm{~g}(1.5 \mathrm{mmol})$ of $\mathrm{Cr}(\mathrm{CO})_{6}$ and $0.12 \mathrm{~g}(1 \mathrm{mmol})$ of 2 are refluxed for $22 \mathrm{~h}$ in $30 \mathrm{ml}$ of $n$-heptane. Evaporation of the red solution and crystallisation of the residue from toluene/petroleum ether, yields $0.05 \mathrm{~g}(25 \%$ yield $)$ of complex $5 \mathrm{a}$.

\section{Reaction with $(\mathrm{MeCN})_{3} \mathrm{~W}(\mathrm{CO})_{3}$}

$0.59 \mathrm{~g}(1.5 \mathrm{mmol})$ of $(\mathrm{MeCN})_{3} \mathrm{~W}(\mathrm{CO})_{3}$ and $0.12 \mathrm{~g}$ $(1 \mathrm{mmol})$ of 2 are refluxed for $15 \mathrm{~h}$ in $40 \mathrm{ml}$ of $n$-hexane. The solution is concentrated and the products separated by chromatography as described above (see Table I).

This work was supported by Consiglio Nazionale delle Ricerche, Roma.

\begin{tabular}{|c|c|c|c|c|c|c|c|c|}
\hline \multirow{2}{*}{ Compound } & \multirow{2}{*}{$\begin{array}{l}\text { M.p. or dec. p. } \\
{\left[{ }^{\circ} \mathrm{C}\right]}\end{array}$} & \multirow{2}{*}{$\begin{array}{l}\text { Found } \\
\text { C }\end{array}$} & \multicolumn{2}{|c|}{ Analysis [\%] } & \multirow{2}{*}{$\begin{array}{l}\text { Calcd. } \\
\text { C }\end{array}$} & \multirow[b]{2}{*}{$\mathrm{H}$} & \multirow[b]{2}{*}{$\mathbf{N}$} & \multirow{14}{*}{$\begin{array}{l}\text { Table III. Analytical data and } \\
\text { melting points of complexes 3-7. }\end{array}$} \\
\hline & & & $\mathrm{H}$ & $\mathrm{N}$ & & & & \\
\hline $\mathbf{B a}$ & 67 & 43.67 & 4.05 & 9.53 & 43.42 & 3.97 & 9.21 & \\
\hline 3b & 107 & 30.54 & 2.84 & 6.45 & 30.29 & 2.77 & 6.42 & \\
\hline $\mathbf{3}^{\prime} \mathbf{a}$ & 88 & 41.03 & 3.86 & 9.04 & 41.25 & 3.78 & 8.75 & \\
\hline $\mathbf{3}^{\prime} \mathbf{b}$ & 104 & 29.33 & 3.01 & 6.29 & 29.22 & 2.68 & 6.20 & \\
\hline $4 a$ & $110-111$ & 49.19 & 6.28 & 14.16 & 49.40 & 6.23 & 14.43 & \\
\hline $4 b$ & $97-99$ & 36.57 & 4.58 & 10.56 & 36.94 & 4.65 & 10.77 & \\
\hline $4^{\prime} \mathbf{a}$ & $123-125$ & 45.45 & 5.79 & 13.45 & 45.71 & 5.75 & 13.33 & \\
\hline $4^{\prime} b$ & $153-154$ & 35.06 & 4.39 & 9.95 & 34.80 & 4.38 & 10.15 & \\
\hline $5 \mathbf{a}$ & 110 & 46.95 & 5.56 & 13.87 & 47.37 & 5.96 & 13.81 & \\
\hline $5 \mathrm{~b}$ & $113-115$ & 33.30 & 3.90 & 9.48 & 33.05 & 4.16 & 9.63 & \\
\hline $6 \mathrm{~b}$ & 123 & 25.64 & 1.62 & 3.81 & 25.29 & 1.59 & 3.69 & \\
\hline $\mathbf{7} \mathbf{b}$ & 180 & 29.80 & 3.22 & 6.52 & 29.43 & 2.96 & 6.86 & \\
\hline
\end{tabular}

[1] Part XVII: A. Albini, H. Kisch, and C. Krüger, Z. Naturforsch. 37 b, 364 (1982).

[2] A. Albini and H. Kisch, Top. Curr. Chem. 65, 105 (1976).
[3] A. Albini and H. Kisch, J. Organomet. Chem. 94, 75 (1975).

[4] P. Mastropasqua, A. Riemer, H. Kisch, and C. Krüger, J. Organomet. Chem. 148, C 40 (1978). 
[5] W. Beck and W. Danzer, Z. Naturforsch. 30b, 716 (1975).

[6] R. Battaglia, H. Matthäus, and H. Kisch, J. Organomet. Chem. 193, 57 (1980).

[7] R. Battaglia, H. Kisch, C. Krüger, and L.-K. Liu, Z. Naturforsch. 35 b, 719 (1980).

[8] M. Herberhold, W. Golla, and K. Leonhard, Chem. Ber. 107, 3209 (1974).

[9] M. N. Ackermann and L. J. Kou, Inorg. Chem. 15, 1423 (1976); J. Organomet. Chem. 86, C 7 (1975).

[10] C. C. Frazier III and H. Kisch, Inorg. Chem. 17, 2736 (1978).
[11] H. Alper and M. Gopal, J. Org. Chem. 46, 2593 (1981).

[12] F. D. Greene and K. E. Gilbert, J. Org. Chem. 40, 1409 (1975).

[13] M. A. Benett, L. Pratt, and G. Wilkinson, in R. B. King (ed.): Transition Metal Compounds, Academic Press, New York 1965, p. 122.

[14] R. B. King and A. Fronzaglia, Inorg. Chem. 5, 1837 (1966).

[15] D. P. Tale, W. R. Knipple, and J. M. Augl, Inorg. Chem. 1, 433 (1961). 